НСБИТОВ А.А.

\title{
СПЕЦІАЛЬНО-КРИМІНОЛОГІЧНІ ЗАХОДИ ЗАПОБІГАННЯ СЕКСУАЛЬНІЙ ЕКСПЛУАТАЦІї
}

Сексуальна експлуатація завдає значної шкоди як психологічному, так і фізіологічному здоров'ю. Для держави, суспільства, кожної людини, яка бере участь у сфері сексуальної експлуатації, найкращим способом вирішення цієї серйозної проблеми було б запобігання злочинам, пов'язаним із сексуальною експлуатацією. Заходи щодо запобігання сексуальній експлуатації можуть здійснюватися не лише на загальносоціальному рівні, але й на спеціальному кримінологічному рівні, хоча вони нерозривно пов'язані між собою. Загальносоціальні заходи - це сукупність зусиль суспільства та держави щодо запобігання злочинам, які слугують основою для формування стратегії боротьби із застосуванням спеціальних кримінологічних заходів.

Спеціально-кримінологічна профілактика злочинності спрямована не тільки на запобігання іiї специфічним проявам із боку певних осіб, але й на ті негативні явища та процеси в суспільстві, які створюють так би мовити, певний рівень і структуру кримінального потенціалу, що виявляється за частотою та тяжкістю скоєних злочинів. Індивідуальні заходи щодо запобігання сексуальній експлуатації включають систему цілеспрямованого організованого з урахуванням педагогічних вимог виховного впливу на свідомість, почуття, волю людини з метою усунення, нейтралізації, блокування іiї негативу і водночас формування позитивних якостей, стереотипи та звички законослухняної поведінки людини.

Спеціальні кримінологічні заходи щодо запобігання сексуальній експлуатації передбачають систематичну роботу державних органів, громадських організацій і громадян над розробленням та реалізацією запланованих дій, пов'язаних із усуненням негативних явищ і процесів, що призводять до суміжних злочинів та сприяють їх вчиненню, а також запобіганням їх реалізації на різних стадіях злочинної діяльності. Така діяльність спрямована на людину або певну групу людей із метою виправити їхню поведінку від антисоціальної до законослухняної.

Ці заходи включають комплексну роботу щодо отримання інформації про реальну загрозу вчинення злочинів, пов'язаних із сексуальною експлуатацією, збирання інформації про спосіб їхнього життя, стосунки та особистість, джерела походження негативних факторів із подальшим плануванням і реалізацією групових заходів чи особистих кроків впливу, моніторинг їхньої подальшої поведінки з метою запобігання загрозі можливого повернення до реалізації намірів щодо вчинення незаконної діяльності загалом і сексуальної експлуатації зокрема.

Ключові слова: запобігання, порнографія, проституція, сексуальна експлуатаичія, сутенерство, торгівля людьми.

Sexual exploitation causes significant harm to both psychological and physiological health. For the state, society, every person involved in the sphere of sexual exploitation, the best way to solve this serious problem would be to prevent the crimes related to sexual exploitation. Measures to prevent sexual exploitation may be implemented not only at the general social level, but also at the special criminological level, although they are inextricably linked. General social measures are a set of efforts of society and the state to prevent crimes and serve as the basis for the formation of a strategy to combat the use of special criminological measures.

( ) НСБИТОВ А.А. - доктор юридичних наук, начальник (Головне управління Національної поліції в Київській області) 
Special-criminological crime prevention is aimed not only at preventing its specific manifestations on the part of certain persons, but also on those negative phenomena and processes in society that create, so to speak, a certain level and structure of criminal potential, which is manifested in the frequency and severity of crimes committed. Individual measures to prevent sexual exploitation include a system of purposeful organized, taking into account pedagogical requirements, educational influence on consciousness, feelings, will of a person in order to eliminate, neutralize, block her negative and, at the same time, the formation of positive qualities, stereotypes and habits of law-abiding human behavior.

Special criminological measures to prevent sexual exploitation provide for the systematic work of state bodies, public organizations and citizens to develop and implement planned actions related to the elimination of negative phenomena and processes that lead to the related crimes and facilitate their commission, as well as prevention their implementation at different stages of criminal activity. Such activities are aimed at a person or a certain group of people in order to correct their behavior from antisocial to law-abiding.

These measures include comprehensive work to obtain information about the real threat of committing crimes related to sexual exploitation, collecting information about their way of life, relationships and personality, sources of origin of negative factors with followed by the planning and implementation of measures of group or personal steps of influence, monitoring their further behavior in order to prevent the threat of a possible return to the realization of intentions regarding the commission of illegal activity in general and sexual exploitation in particular.

Key words: prevention, pornography, prostitution, sexual exploitation, pimping, trafficking in human beings.

Вступ. Сексуальна експлуатація являє собою складне явище, що є індикатором соціального, економічного становища країни, піддається сукупному впливові причинності злочинності та являє собою одну з форм експлуатації, яка на основі комерційної угоди полягає у використанні проти волі людини її фізичних здібностей (можливостей) для задоволення власних сексуальних потреб або потреб іншої особи (осіб) з метою отримання суб'єктом експлуатації фінансової або іншої вигоди. Реальні масштаби сексуальної експлуатації значно більші від загальної кількості зареєстрованих злочинів. Соціально-економічні фактори зумовлені здебільшого зростанням рівня безробіття та важкого матеріального становища. Водночас під час сексуальної експлуатації людини значна шкода завдається як ії психологічному, так і фізіологічному здоров’ю. Для держави, суспільства, кожної особи, втягнутої до сфери сексуальної експлуатації, найкращим способом вирішення цієї болючої проблеми було би запобігання злочинам, пов'язаним із сексуальною експлуатацією.

Аналіз останніх досліджень і публікацій. Свою увагу дослідженню різних питань, пов'язаних із запобіганням сексуальній експлуатації, приділяли такі вчені, як В.В. Василинчук, В.К. Весельський, В.Я. Горбачевський, О.М. Джужа, О.М. Смець, К.Б. Левченко, В.Б. Розвадовський, Т.А. Шевчук, С.С. Чернявський та інші. Проте проблема протидії подібним правопорушенням залишається актуальною, адже під час вчинення злочинів, пов'язаних із сексуальною експлуатацією, руйнується життя втягнутих у протиправну діяльність людей, а також ставиться під загрозу генофонд нації, посилюється демографічна криза в країні тощо. Цим обгрунтовується поставлена нами мета щодо вдосконалення системи спеціально-кримінологічних заходів запобігання сексуальній експлуатації.

Постановка завдання. Метою статті є аналіз спеціальних кримінологічних заходів щодо запобігання сексуальній експлуатації.

Результати дослідження. Заходи запобігання сексуальній експлуатації можуть здійснюватися не лише на загальносоціальному рівні, а й на спеціально-кримінологічному, хоча вони нерозривно поєднані між собою. Загальносоціальні заходи є сукупністю зусиль суспільства й держави щодо профілактики злочинів і виступають підгрунтям для формування стратегії боротьби 3 використанням спеціально-кримінологічних заходів [1, с. 31]. Основною відмінністю спеціально-кримінологічних заходів запобігання від загальносоціальних є те, що їхня дія має тактичне спрямування, а не стратегічне [2, с. 218-221]. Диференціація запобігання злочинності на загальносоціальну і спеціально-кримінологічну має певною мірою умовний характер. $Є$ низка 
заходів, які поєднують у собі риси загальносоціальної і спеціальної профілактики [3, с. 56]. С.Г. Кулик, досліджуючи питання про спеціально-кримінологічні заходи запобігання злочинам проти моральності, пише, що вони, безумовно, повинні мати комплексний і системний характер, а також впроваджуватись одночасно з успішною реалізацією запобіжних загальносоціальних заходів. Спеціально-кримінологічні форми впливу у цьому разі мають багаторівневий характер і повинні застосовуватись у тісному зв'язку із загальносоціальними заходами [4, с. 141-143].

Теорія і практика розроблення та реалізації методів і заходів руйнівного впливу на явища та процеси, які зумовлюють або можуть зумовлювати активізацію криміногенного потенціалу суспільства у виді злочинних проявів, а також недопущення їх здійснення на різних стадіях злочинної поведінки, тобто на стадіях формування кримінальної мотивації, виникнення умислу на вчинення злочину, готування до злочину та замаху на злочин, називаються спеціально-кримінологічним запобіганням злочинності. Спеціально-кримінологічне запобігання не простий і не випадковий набір певних заходів, а комплекс науково обгрунтованих, практично необхідних і реально здійснюваних заходів, спрямованих саме на недопущення потенційних злочинів на різних етапах їх кримінального формування. Спеціально-кримінологічне запобігання злочинності спрямоване не тільки на недопущення конкретних її проявів із боку певних осіб, а й на ті негативні явища й процеси в суспільстві, які створюють, так би мовити, певний рівень і структуру криміногенного потенціалу, що виявляється в частоті й тяжкості вчинених злочинів [5].

М.М. Биргеу зазначає, що спеціально-кримінологічне запобігання включає, перш за все, комплекс цілеспрямованих заходів, що призначені виключно на боротьбу зі злочинністю та здійснюються органами та організаціями, які наділені нормативно визначеними функціями, безпосередньо пов'язаними 3 протидією злочинності [6, с. 66]. Це заходи, спрямовані на виявлення, усунення, послаблення, нейтралізацію криміногенних факторів, а також вплив на осіб, які можуть вчинити злочин. На рівні спеціальної профілактики мета боротьби зі злочинністю, іiі окремими видами і конкретними злочинами визначена як єдина, чи головна, для відповідних заходів соціального контролю, соціальної реабілітації або правоохоронної діяльності. Розроблення та реалізація спеціальних заходів прямо обумовлені наявністю злочинності, її рівнем і характером, впливом криміногенних детермінант [3, с. 56]. Завдання спеціально-кримінологічних заходів запобігання злочинності полягає у недопущенні можливих злочинів на різних стадіях їх вчинення та у здійсненні відповідного впливу на тих осіб, які вже вчинили злочин (злочини) [7, с. 168]. Об'єктами для проведення такої роботи є [8]:

- антигромадська поведінка та спосіб життя особи, що призводять до вчинення злочинів;

- кримінологічно значущі особистісні характеристики людини, що зумовлюють деформацію поведінки;

- кримінологічно значущі психофізіологічні особливості (у міру їх схильності до виправлення, зміни, лікування);

- безпосередні умови несприятливого формування та життєдіяльності особистості насамперед у родині або побутовому оточенні, у сферах праці, навчання, дозвілля, в інших мікросоціальних групах, передусім антигромадської спрямованості, а також несприятливі умови індивідуального буття;

- елементи несприятливої життєвої ситуації, які об’єктивно мають криміногенний характер і існують досить тривалий час.

Йдеться про спільну роботу державних органів, громадських організацій, соціальних груп і громадян, спрямовану на усунення причин та умов, що породжують і сприяють сексуальній експлуатації, а також недопущення вчинення пов'язаних із нею злочинів на різних стадіях протиправної поведінки. Запобігання злочинам складається із сукупності заходів, спрямованих на окремі групи та конкретних осіб, які виношують злочинні наміри, замислюють вчинення злочинів і позитивно сприймають злочинний спосіб життя, з метою дискредитування злочинної поведінки, відмови від злочинної мотивації та наміру або продовження злочинної діяльності. Запобігання злочинності треба розглядати як сукупність видів діяльності, які виконуються з метою усунення вірогідності вчинення задуманих злочинів шляхом розроблення і здійснення цілеспрямованих заходів. Запобіжні заходи протидії злочинній мотивації доцільно розділити на дві групи: заходи переорієнтації антисуспільної установки та активні контрзаходи. До останніх відносять засновані на оперативній інформації заходи переконання, різні форми примусу, застереження потенційних потерпілих про можливість злочинного посягання і допомоги потенційним злочинцям із метою відвернення злочину або рецидиву злочину. Заходи переорієнтації антисуспільної установки включають створення і підтримання на належному рівні [9]: 
- спеціальних економічних і соціально-психологічних програм, які розраховані на те, щоб людина в суспільстві отримувала повне задоволення своїх потреб і відмовлялась від злочинних намірів;

- організаційно-правових заходів, які підвищують у людей почуття відповідальності і виробляють у них уявлення про допустимі засоби досягнення своїх потреб;

- кримінологічної поінформованості населення для його більш тісного співробітництва 3 правоохоронними органами.

Т.А. Шевчук наголошує, що особливе місце в комплексі спеціально-кримінологічних заходів запобігання злочинам, пов'язаним із сутенерством та втягненням особи в заняття проституцією, посідає морально-правове виховання. Саме воно покликане позитивно впливати на формування особистості, правильно спрямовувати іiї поведінку з метою подальшого усвідомлення нею аморальності, протизаконності подібної поведінки. Морально-правове виховання $є$ частиною культурного виховання населення, що включає в себе низку заходів запобігання поширенню цього злочину. Підкреслюється, що особливу увагу в цьому напрямі слід приділяти розвитку на сучасному етапі системи статевого виховання, яке впливає на мораль, орієнтації, погляди, інтереси й мотиви вчинків людей $[10$, с. 11$]$.

Індивідуальні заходи запобігання сексуальній експлуатації передбачають систему цілеспрямованого, організованого, з урахуванням педагогічних вимог, виховного впливу на свідомість, почуття, волю особи з метою усунення, нейтралізації, блокування у неї негативних і одночасно формування позитивних рис, стереотипів і звичок законослухняної поведінки [11]. До таких заходів належать [8]:

- профілактична бесіда - застосовується за наявності інформації про те, що особа вчинила протиправні дії, які можуть призвести до вчинення злочину, з метою роз'яснення суспільної небезпечності та усного попередження про неприпустимість протиправних і антигромадських дій;

- офіційне застереження - особі оголошується офіційне застереження про неприпустимість протиправної поведінки та можливі заходи профілактичного впливу;

- профілактичний облік - застосовується для систематичного і цілеспрямованого здійснення індивідуальних заходів щодо особи, поведінка якої свідчить про реальну можливість вчинення нею злочину (тому така особа підлягає взяттю на профілактичний облік);

- адміністративний контроль - застосовується до особи, щодо якої встановлюється, здійснюється та припиняється адміністративний нагляд;

- соціальний патронаж - це комплекс заходів державної підтримки та допомоги щодо особи, яка потребує іï.

Значних зусиль щодо запобігання сексуальній експлуатації докладає Міжнародний жіночий правозахисний центр «Ла Страда-Україна», який організовує та забезпечує роботу [12]:

- національної гарячої лінії з протидії торгівлі людьми;

- національної гарячої лінії з протидії домашньому насильству та захисту прав дитини;

- електронної гарячої лінії з протидії дитячій порнографії в Інтернеті.

Людина, яка збирається виїхати за кордон на заробітки чи з іншою метою, отримує кваліфіковану допомогу юристів про те, як належним чином оформити відповідні документи та уникнути потрапляння до тенет торговців «живим товаром». Крім того, людині, яка звернулася до правозахисного центру з інформацією про факти сексуальної експлуатації, якщо дозволяють обставини, рекомендують звернутися до правоохоронних органів.

Завдання щодо запобігання сексуальній експлуатації покладено насамперед на органи Національної поліції, до якої структурно входять оперативні підрозділи, що здійснюють запобіжні заходи в цій сфері відповідно до своїх повноважень. Наприклад, 3 травня 2000 р. було створено окремий оперативний підрозділ для боротьби зі злочинами, пов'язаними з торгівлею людьми, який пізніше набув статусу Департаменту. Однак до запобігання сексуальній експлуатації залучаються й інші оперативні підрозділи Національної поліції України, зокрема карного розшуку, кримінальної розвідки, захисту економіки, оперативної служби, оперативно-технічних заходів, протидії наркозлочинності, кіберполіції, в межах своєї компетенції та залежно від обставин противоправної діяльності. Важливу роль у запобіганні сексуальній експлуатації відіграють й інші підрозділи Національної поліції України, які не $є$ оперативними, зокрема слідчі, Робочий апарат Укрбюро Інтерполу, дільничні офіцери поліції.

До проведення спеціально-кримінологічних заходів запобігання сексуальній експлуатації залучаються також інші правоохоронні та державні органи, насамперед Служба безпеки України, Державна прикордонна служба України та прокуратура. Крім того, правоохоронні органи під 
час проведення заходів із запобігання сексуальній експлуатації активно взаємодіють із різними неурядовими організаціями, насамперед такими як Міжнародний жіночий правозахисний центр «Ла Страда-Україна», Всесвітня мережа за виживання, Коаліція проти незаконного вивозу жінок, Всесвітній альянс проти незаконного вивозу жінок.

Співробітництво правоохоронних органів України та інших країн як загалом, так і у сфері спеціально-кримінологічного запобігання сексуальній експлуатації здійснюється за допомогою Міжнародної організації кримінальної поліції Інтерпол, що забезпечує організацію та координацію спільної діяльності. У структурі директорату з окремих видів злочинів Генерального Секретаріату Інтерполу створено спеціальний відділ протидії злочинам, пов'язаним із торгівлею людьми. Взаємодія також здійснюється за допомогою Європейської поліцейської установи Європолу, що координує певні операції, наприклад, із перекриття каналів вивозу з України до Євросоюзу жінок для сексуальної експлуатації. Багато зусиль для забезпечення взаємодії правоохоронних органів України та інших країн у запобіганні сексуальній експлуатації докладають міжнародні організації, зокрема Організація з безпеки і співробітництва в Європі, Міжнародна організація 3 міграції, Міжнародна організація праці, Організація за демократію та економічний розвиток ГУАМ, Регіональний центр Південно-Східної Європейської ініціативи (SECI).

Висновки. Проведене дослідження питання про спеціально-кримінологічні заходи запобігання сексуальній експлуатації дає можливість дійти певних висновків. Зокрема, в Україні заходи запобігання сексуальній експлуатації проводяться не тільки на загальносоціальному рівні, а також і на спеціально-кримінологічному. Незважаючи на те, що вони нерозривно поєднані між собою, останні мають не стратегічний, а тактичний характер, хоча їх впровадження базується на успішній реалізації загальносоціальних запобіжних заходів. Спеціально-кримінологічні заходи запобігання сексуальній експлуатації передбачають системну роботу державних органів, громадських організацій і громадян щодо розроблення й реалізації запланованих дій, пов'язаних з усуненням негативних явищ і процесів, які зумовлюють пов'язані з нею злочини та сприяють їх вчиненню, а також недопущення їх здійснення на різних стадіях кримінальної діяльності.

Спеціально-кримінологічні заходи запобігання сексуальній експлуатації спрямовуються на людину або певну групу людей із метою корекції їхної поведінки від антигромадської до законослухняної. Такі заходи передбачають комплексну роботу щодо отримання інформації про реальну загрозу вчинення ними злочинів, пов'язаних із сексуальною експлуатацією, збір відомостей про спосіб їхнього життя, зв'язки та особистість, джерела походження негативних чинників із наступним плануванням і проведенням заходів групового або персонального запобіжного впливу, моніторингом подальшої їхньої поведінки для відвернення загрози можливого повернення до реалізації задумів щодо вчинення протиправної діяльності загалом і сексуальної експлуатації зокрема.

\section{Список використаних джерел:}

1. Остапенко Я.С. Спеціально-кримінологічні заходи запобігання службовому підробленню. Науковий вісник Херсонського державного університету. Серія : Юридичні науки / Херсонський державний університет. Херсон, 2016. Вип. № 1. Т. 4. С. 31-34.

2. Рубан К.П. Спеціально-кримінологічні та індивідуальні заходи протидії злочинності в місцях позбавлення волі. Право і безпека. 2012. № 3. С. 218-221.

3. Кримінологія : навч. посіб. / О.М. Джужа, В.В. Василевич, О.Г. Колб та ін. ; за заг. ред. д-ра юрид. наук, проф. О.М. Джужи. Київ : Атіка, 2009. 312 с.

4. Кулик С.Г. Спеціально-кримінологічні заходи запобігання злочинам проти моральності. Держава та регіони. Серія : Право / Класичний приватний університет. Запоріжжя, 2012. № 4 (38). C. 141-143.

5. Голіна В.В. Запобігання злочинності (теорія і практика) : навч. посіб. Харків : Нац. юрид. акад. України, 2011. 120 с.

6. Быргэу М.М. Организация профилактики преступлений органами внутренних дел: концептуальные основы, практика, перспективы совершенствования (опыт Республики Молдова) : монография / под. общ. ред. А.М. Бандурки. Харьков : Изд-во Нац. ун-та внутр. дел, 2004. 253 с.

7. Чабаненко С.М. Спеціально-кримінологічні заходи запобігання незаконному використанню коштів позабюджетних цільових фондів. Науковий часопис Національної академії Прокуратури Украӥни. 2015. № 4. С. 166-174.

8. Профілактика злочинів : підручник / О.М. Джужа, В.В. Василевич, О.Ф. Гіда та ін. ; за заг. ред. д-ра юрид. наук, проф. О.М. Джужи. Київ : Атіка, 2011. 720 с. 
9. Кримінологія: Загальна та Особлива частини : підруч. для студ. юрид. спец. вищ. навч. закл. / І.М. Даньшин, В.В. Голіна, О.Г. Кальман, О.В. Лисодєд ; за ред. проф. І.М. Даныиина. Харків : Право, 2003. 352 с.

10. Шевчук Т.А. Сутенерство та втягнення особи в заняття проституцією: кримінологічна характеристика і запобігання : автореф. дис. ... канд. юрид. наук : спец. 12.00.08. Харків, 2011. 23 с.

11. Алексеев А.И., Сахаров А.Б. Причины преступлений и устранение их органами внутренних дел. Москва, 1982. 47 с.

12. Міжнародний жіночий правозахисний центр «Ла Страда-Україна». URL: http://la-strada.org.ua.

УДК 343.13:343.123

DOI https://doi.org/10.32844/2618-1258.2019.3-2.34

НІКОЛАЙЧУК Г.А.

\section{ВІДМОВА ПРОКУРОРА ВІД ПІДТРИМАННЯ ПУБЛІЧНОГО ОБВИНУВАЧЕННЯ В РАЗІ ЙОГО ПІДТРИМАННЯ ГРУПОЮ ПРОКУРОРІВ}

У статті розглядаються питання, пов'язані з відмовою прокурора від підтримання публічного обвинувачення в суді. Акцентується увага на особливостях такої відмови в разі створення групи прокурорів.

Встановлено, що відмова прокурора від підтримання публічного обвинувачення можлива лише в тих випадках, коли не встановлено подію злочину; в діянні обвинуваченого нема складу злочину; не доведено участь обвинуваченого у вчиненні злочину.

Прокурор, що входить до складу прокурорської групи, повинен здійснювати процесуальні дії в конкретному кримінальному провадженні в межах дорученої ділянки роботи (при цьому не втрачаючи процесуальної самостійності), а процесуальні рішення узгоджувати із старшим групи. Питання про те, хто ж із групи прокурорів за наявності до того підстав повинен ініціювати питання про відмову прокурора від підтримання публічного обвинувачення, $\epsilon$ невирішеним.

3'ясовано, що відповідно до чинного законодавства прокурор, який підтримує публічне обвинувачення в суді і не $є$ старшим групи прокурорів, повинен ініціювати питання про відмову від підтримання публічного обвинувачення перед старшим групи. При цьому ані форма, ані зміст такої ініціативи законодавчо не закріплені. Також неврегульованим є питання стосовно необхідних процесуальних дій старшого прокурорської групи, який не згоден із позицією публічного обвинувача про потребу відмови від обвинувачення. Це на практиці призводить до ситуації, коли через незгоду старшого прокурора групи з позицією працівника підпорядкованої прокуратури про необхідність відмови від підтримання публічного обвинувачення прокурор прокуратури нижчого рівня змушений підтримувати публічне обвинувачення всупереч внутрішньому переконанню.

Відстоюється думка, що в такій та подібних ситуаціях слід керуватися колізійним ієрархічно-правовим принципом, відповідно до якого в разі суперечностей між положеннями нормативно-правових актів різної юридичної сили перевагу має вищий за юридичною силою. Поза всяким сумнівом, закон (КПК України) повинен мати пріоритет над підзаконним нормативно-правовим актом (хай навіть і наказом Генерального прокурора).

Ключові слова: відмова, група прокурорів, обвинувачення, провадження, судовий розгляд.

НІКОЛАЙЧУК Г.А. - аспірант кафедри кримінального процесу та криміналістики (Львівський національний університет імені Івана Франка) 